\title{
"How to use it more?" Self-efficacy and its sources in the use of social media for knowledge sharing
}

\author{
Hussain Alshahrani \\ Department of Computer and Information Sciences, University of Strathclyde, Glasgow, UK \\ andShaqra University, Shaqra, Saudi Arabia \\ Diane Rasmussen Pennington \\ Department of Computer and Information Sciences, University of Strathclyde, Glasgow, UK
}

\begin{abstract}
Purpose - This study investigated sources of self-efficacy for researchers and the sources' impact on the researchers' use of social media for knowledge sharing. It is a continuation of a larger study (Alshahrani \& Rasmussen Pennington, 2018).

Design/methodology/approach - The authors distributed an online questionnaire to researchers at the University of Strathclyde $(n=144)$ and analysed the responses using descriptive statistics.

Findings - Participants relied on personal mastery experience, vicarious experience, verbal persuasion, and emotional arousal for social media use. These elements of self-efficacy mostly led them to use it effectively, with a few exceptions.

Research limitations/implications - The convenience sample utilised for this study, which included academic staff, researchers, and $\mathrm{PhD}$ students at one university, is small and may not be entirely representative of the larger population.

Practical implications - This study contributes to the existing literature on social media and knowledge sharing. It can help researchers understand how they can develop their selfefficacy and its sources in order to enhance their online professional presence. Additionally, academic institutions can use these results to inform how they can best encourage and support their researchers in improving their professional social media use.

Originality/value - Researchers do rely on their self-efficacy and its sources to use social media for knowledge sharing. These results can help researchers and their institutions eliminate barriers and improve online engagement with colleagues, students, the public, and other relevant research stakeholders.
\end{abstract}

Keywords - Self-efficacy, Social media, Knowledge sharing, Social cognitive theory, Researchers, Barriers

\section{Introduction}

In the last few years, social media has been increasingly used as a tool for communicating and sharing. Facebook, Twitter, LinkedIn, YouTube, and others are frequently utilised to facilitate sharing of ideas, pictures, comments, and other forms of knowledge (Kaplan \& Haenlein, 2010). Sharing knowledge amongst researchers can assist them in improving and developing ideas; social media is obviously one way to accomplish this (Panahi, Watson, \& Partridge, 2016). Indeed, social media use for knowledge sharing can remove the space and time constraints that occur when using more traditional methods of communication (Fotis, 2015). In the process of sharing knowledge through social media, researchers can discuss ideas, and develop topics, present their professional selves virtually, and share their outputs (Panahi et al., 2016; Alshahrani \& Rasmussen Pennington, 2018; Veletsianos, 2016, Carrigan, 2016; Ellison, Gibbs, \& Weber, 2015). "Online, researchers can share what they have learnt and practiced in 
their work as well as what they have produced as written communication" (Alshahrani \& Rasmussen Pennington, 2018, p. 1275).

Previous studies have investigated either how social media platforms facilitate knowledge sharing or the factors that affect this use (e.g. Bilgihan, Barreda, Okumus, \& Nusair, 2016; Cheung, Lee, \& Lee, 2013; Cho, Chen, \& Chung, 2010; Eid \& Al-Jabri, 2016; Kwahk \& Park, 2016; Ma, Lee, \& Goh, 2014; Oh \& Syn, 2015), but these areas need more investigation, as the research is still in its early stages (Edwards, Cheng, Wong, Zhang, \& Wu, 2017; Panahi, Watson, \& Partridge, 2012b; Razmerita, Kirchner, \& Nabeth, 2014). Moreover, not all researchers use it effectively for sharing knowledge (Greifeneder et al., 2018). This may be due to weaknesses in their self-efficacy, which is considered to be one of the most important factors that influence the use of social media for knowledge sharing (Cheung et al., 2013; Cho et al., 2010; Kwahk \& Park, 2016; Vuori \& Okkonen, 2012). Defined as “a judgment of one's capability to accomplish a certain level of performance" (Bandura, 1986, p. 391), individuals construct and obtain self-efficacy from four main sources: performance accomplishments, vicarious experience, verbal persuasion, and emotional arousal (Bandura, 1977). In this paper, self-efficacy specifically refers to researchers' ability to use social media effectively for sharing knowledge. The first part of this larger study investigated these sources and their impact on researchers' use of social media for knowledge sharing through semi-structured qualitative interviews (Alshahrani \& Rasmussen Pennington, 2018). The current paper builds on the qualitative results with a quantitative approach to gain a broader perspective on the topic.

\section{Literature Review}

\subsection{Self-efficacy and its sources}

Self-efficacy is one of the two most important elements of social cognitive theory (Bandura, 1986). Its focus is on the capability of individuals to achieve a certain level of performance (Bandura, 1986). The importance of self-efficacy and its impact on behaviours and skills have been widely investigated by several studies (e.g. Celik \& Yesilyurt, 2013; Gegenfurtner, Veermans, \& Vauras, 2013; Pajares \& Kranzler, 1994; Pajares \& Miller, 1994, 1995).

The importance of self-efficacy may include improving performance (Bandura, 1977, 1986; Wiedenbeck, 2005; Wiedenbeck, Labelle, \& Kain, 2004), achieving goals (Bandura, 1994), expending effort (Askar \& Davenport, 2009; Bandura, 1977, 1982, 1986, 1994), facing challenges and difficulties (Bandura, 1977, 1982, 1986, 1994), maintaining resilience after failures (Bandura, 1994), and making decisions (Askar \& Davenport, 2009; Bandura, 1977, 1982, 1986). Bandura (1994) said, "self-efficacy affects life choices, level of motivation, quality of functioning, resilience to adversity and vulnerability to stress and depression" ( $\mathrm{p}$. $80)$.

As stated previously, self-efficacy has four sources, which individuals are responsible for constructing (Bandura, 1977). Personal mastery experiences refer to past experiences that positively or negatively influence individuals' perceived ability (Alshahrani \& Rasmussen Pennington, 2018). It is the most influential source in building confidence for individuals (Hendricks, 2016).

The second source, vicarious experience, is "the mimicry of other researchers who effectively use social media for knowledge sharing by observing their performance and successes, and then attempting to replicate their behaviours" (Alshahrani \& Rasmussen Pennington, 2018, p. 
1275). Individuals can build their self-efficacy indirectly by observing others' activities (Bandura, 1977), which can lead them to believe that they are able to do what others do.

Verbal persuasion, the third source, refers to encouragement received from colleagues, friends, family, and institutions (Alshahrani \& Rasmussen Pennington, 2018; Bandura, 1977). This encouragement motivates individuals to believe that they have the ability to achieve a high level of performance (Tschannen-Moran \& McMaster, 2009).

The final source, emotional arousal, refers to psychological reactions and feelings toward the activity. It can create psychologically stressful situations for individuals, depending on the circumstances (Bandura, 1977). Specifically, positive and negative emotions can leave researchers with either positive or negative perceptions of using social media to share knowledge (Hendricks, 2016).

Many researchers have studied the four sources of self-efficacy. For example, Usher and Pajares (2008) completed a critical review of related literature for the period between 1990 and 2007; most were quantitative and focused on education and performance. Joët, Usher, and Bressoux (2011) studied the influence of these sources on the academic and self-regulatory efficacy beliefs of third grade elementary school students; the sources and mean classroom level predicted self-efficacy for self-regulated learning. Likewise, Loo and Choy (2013) found in a study of 178 third year engineering students that sources were correlated, but the main predictor for academic achievement of mathematics and related engineering modules was personal mastery experience. In Warner et al. (2014), mastery experience, self-persuasion, and a reduction in negative affective states were significant predictors of self-efficacy for physical activity in community-dwelling older adults. Garlin and McGuiggan (2002) investigated the sources of self-efficacy in consumer behaviour through 10 in-depth interviews, which provided supporting evidence for the significance of these sources and their impact on self-efficacy in the course of consumption.

Alshahrani and Rasmussen Pennington (2018) conducted semi-structured interviews with 30 researchers and found that they do rely on these four sources substantially in their use of social media. They argued for a need to further investigate with a quantitative approach to gain additional insight, which is the aim of the current paper.

\subsection{Knowledge Sharing}

In the last decade, researchers and scholars have paid substantial attention to knowledge sharing (Alshahrani \& Rasmussen Pennington, 2018); one result of this has been the development of several operational definitions for the term. For instance, it has been described a set of behaviours that includes exchanging knowledge with others (Chow \& Chan, 2008; Connelly \& Kelloway, 2003), transferring knowledge from one person, group or organisation to another (Bukowitz \& Williams, 2000; Lee, 2001), and a social interaction for exchanging experience and skills (Šajeva, 2014; Zawawi et al., 2011). According to Alshahrani and Rasmussen Pennington (2018), knowledge sharing is "a process of interactions through which knowledge is exchanged between individuals, groups, and organisations. This interactive exchange occurs through the use of social media, which is highly interactive" (p. 1277).

Knowledge sharing can promote the process of learning and understanding. Through sharing, individuals both teach and learn, leading to professional and personal selfimprovement (Brown, Dennis, Burley, \& Arling, 2013). Srivastava, Bartol, and Locke (2006) stated, "Knowledge sharing may lead to better team performance for at least two reasons: improved decision making, and coordination" (p. 1242). According to Collins (2010); Nonaka and Von Krogh (2009); Polyani (1966), there are two types of knowledge: tacit and explicit. 
Tacit knowledge resides in an individual's mind and stems from experiences and personal beliefs (Panahi, Watson, \& Partridge, 2012a). In contrast, explicit knowledge can be articulated into words and numbers which can be formally and systematically shared in written and verbal communication. (Al-Taee, 2014; Becerra-Fernandez \& Sabherwal, 2014; Kothari et al., 2012).

Social media is a powerful way to share knowledge (Alshahrani \& Rasmussen Pennington, 2018), and previous studies have explored this. For example, Panahi (2014) completed a qualitative study of physicians that showed social media use facilitates tacit knowledge sharing in 21 different ways. Cheung et al. (2013); Cho et al. (2010); Kwahk and Park (2016) showed that self-efficacy was one of the most important factors in social media knowledge sharing, but did not investigate the sources of self-efficacy, which is the gap that the current study sought to fill.

\subsection{Researchers' Use of Social Media}

Researchers can play a vital role for creating and disseminating knowledge, and they are the best examples of those who share knowledge (Jolaee, Md Nor, Khani, \& Md Yusoff, 2014). It is therefore "useful to explore how researchers implement knowledge sharing with others and what channels they use" (p. 1278). As mentioned, they use it to share resources, explanations, or ideas to enhance their knowledge (Veletsianos, 2016). They also use it to present their work and increase their visibility in their discipline (Alshahrani \& Rasmussen Pennington, 2018). Academic social media platforms (e.g. Academia.edu and ResearchGate) can archive and categorise research papers in specific ways to make them readily findable and available for others (Carrigan, 2016). More general platforms such as Twitter and Facebook can be used to announce new publications, and to share links to them (Carrigan, 2016). It allows researchers from various disciplines to interact, inspire, build friendships, and share news (Veletsianos, 2017). It can be utilised to distribute final results, solve problems, and obtain constructive feedback (Jabr, 2011). However, researchers need self-efficacy in order to accomplish these tasks.

Researchers have also studied how self-efficacy can influence the use of social media for knowledge sharing. For instance, Cho et al (2010) investigated how and why people participate in knowledge building practices on Wikipedia; self-efficacy significantly influenced these practices. Papadopoulos, Stamati, and Nopparuch (2013) argued that self-efficacy has a positive effect on employees' use of weblogs for knowledge sharing. As Alshahrani and Rasmussen Pennington (2018) concluded, despite its importance, no attention seems to have been paid to the sources of self-efficacy and their impact on researchers' use of social media to share knowledge.

\section{Methodology}

The authors designed an online questionnaire based on the results emerging from the 30 semistructured interviews that took place earlier in the larger study (Alshahrani \& Rasmussen Pennington, 2018). They used the quotes to identify items of interest, the codes to develop grouping variables, and the themes to group variables into scales. According to Creswell (2014), this procedure is useful for developing quantitative scales from qualitative findings.

\subsection{Quantitative data collection}

The researchers distributed the online questionnaire using Qualtrics. Online surveys are easy to use and inexpensive compared to alternative survey methods (Evans \& Mathur, 2005; Harlow, 2010; Van Selm \& Jankowski, 2006). They are valuable for collecting data from respondents in one or many locations (Evans \& Mathur, 2005), and are more flexible than other 
survey types (Evans \& Mathur, 2005; Harlow, 2010). They are also the most efficient way to obtain information from a large sample (Evans \& Mathur, 2005).

The questionnaire was used to generalise and validate the findings from the qualitative portion of the study (Muijs, 2011). The questionnaire (see Appendices 1 and 2) covered the four sources of self-efficacy: personal mastery experiences, vicarious experience, verbal persuasion, and emotional arousal. The questionnaire contained mostly closed-ended questions, although some questions allowed participants to contribute open-ended comments and explanations.

Realising that some participants might not use social media to share knowledge, the authors created survey logic to first determine whether they do. If participants selected 'Yes', they were provided questions pertaining to its use. If they selected 'No', they were asked a separate set of questions to determine why not. In addition, the questionnaire requested basic demographic information such as types and platforms of social media used, gender, position, faculty, and years of research experience. The questionnaire was distributed to academic staff, researchers, and $\mathrm{PhD}$ students at the University of Strathclyde. The authors emailed departmental administrators and secretaries with a request to forward their survey invitation to researchers in their departments. They also used Twitter for recruitment.

A total of 144 participants, with representation from all four faculties at the university, completed the questionnaire. The sample was a limitation; it was a self-selected convenience sample, and due to low response rates from senior researchers, the majority of participants in this study were $\mathrm{PhD}$ students. Because of the skewed sample, this study cannot make comparisons between the different levels of researchers, although there is indirect evidence to support the claim that there is no difference between these levels, as will be shown below.

\subsection{Quantitative data analysis}

The authors used descriptive statistics to analyse responses. According to Fisher and Marshall (2009), "Descriptive statistics provide us with a useful strategy for summarising data and providing a description of the sample but cannot provide information for causal analysis" ( $p$. 97), which allows people to understand the composition of the sample more easily (Cottrell \& McKenzie, 2010). Descriptive statistics provide alternative information, and measure normality and frequency distributions to characterise the data, rather than test significance levels and hypotheses (Cliff \& King, 1996). Pallant (2013) stated that descriptive statistics are used to describe the characteristics of the sample, to verify the variables and the statistical techniques that will be used, and to address specific research questions.

Descriptive statistics are mostly used to examine central tendency (mean, median, and mode), dispersion (range, variance, and standard deviation) (Pallant, 2013; Pickard, 2013), as well as skewness and kurtosis (Pallant, 2013). The authors used measures of central tendency and dispersion to outline the data accurately, whereas they used skewness and kurtosis to determine whether the variables are normally distributed. Subsequently, independent samples t-tests were carried out to compare means of sources of self-efficacy and their impact. This was to determine whether the difference between senior researchers and $\mathrm{PhD}$ students was statistically significant at the 0.05 level.

Most of the questions in the survey were answered using five-point Likert scales, in which $1=$ "strongly disagree" and 5 = "strongly agree". However, some variables received a code of " 1 " 
if the respondent chose it as an answer or a " 0 " if not. Another type of question also received a code " 1 " if the respondent chose "Yes" and a "0" if "No".

Using IBM SPSS Statistics 24 and Excel 2016, the authors used frequency to analyse demographic and general information such as gender, position, Faculty, years of experience, types of social media, social media platforms, and barriers. They used mean and standard deviation to analyse data that related to key concepts.

To validate the questionnaire, the authors used content validity. According to DeVellis (2016); Frey (2006), content validity refers to what extent a specific set of items reflects a content domain. Thus, the content validity in this study started from the developmental stage of the questionnaire when the authors asked experts in the field to review the questionnaire.

The authors used Cronbach's alpha to calculate internal consistency. According to Bryman (2012), "Nowadays, most researchers use a test of internal reliability known as Cronbach's alpha. Its use has grown as a result of its incorporation into computer software for quantitative data analysis" (p. 170). The scores of Cronbach's alpha in this study ranged from .80 to .86 for all scales, which shows a good level of internal consistency for the items.

\section{Results}

This section reports the results from the descriptive statistical analysis. It includes demographics of the sample, and the sources of self-efficacy and their impact.

\subsection{Response rate and demographics}

There were 222 responses: 144 completed responses $(65 \%)$ and 78 incomplete responses (35\%). The incomplete responses were excluded from the analysis.

There were 77 male (53.5\%) and 63 female (43.7\%) participants, while four participants $(2.8 \%)$ preferred not to specify a gender (See Figure 1).

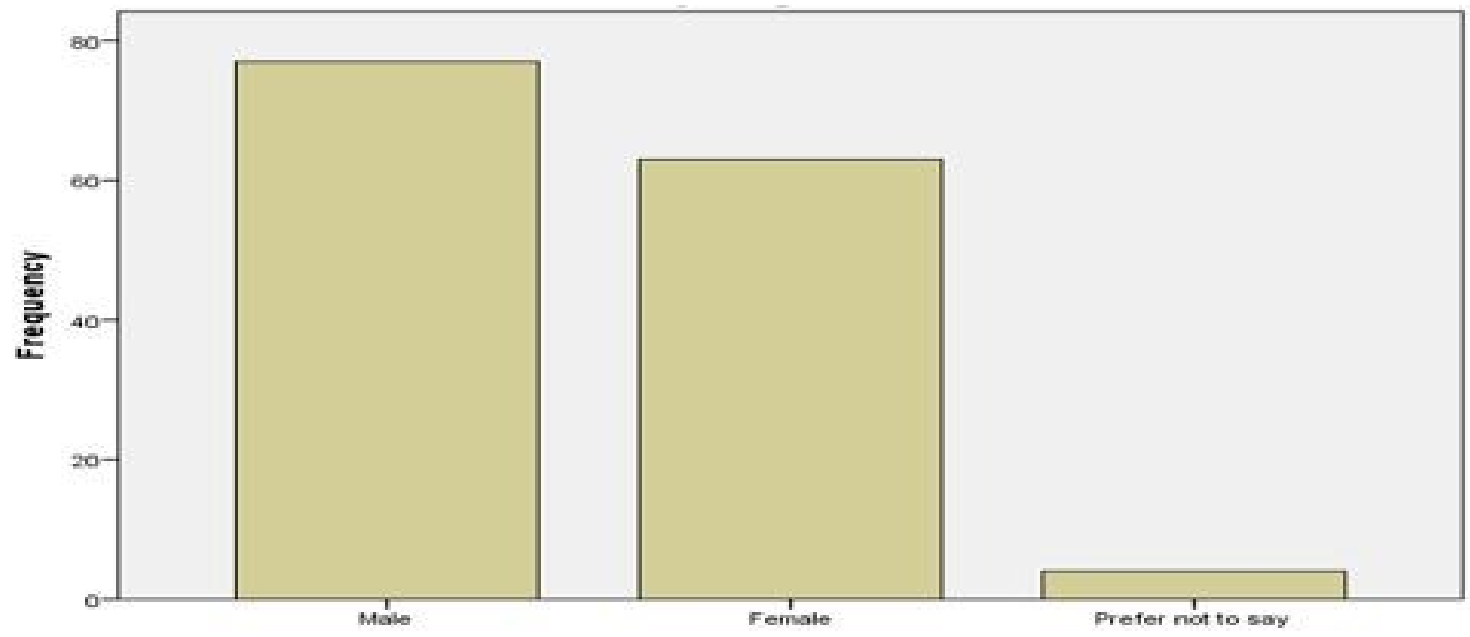

Figure 1: Participants' Gender

The majority of respondents (53.5\%), were PhD students, followed by Research Associates at $11.1 \%$, Research Assistants at 9.7\%, Professors and Lecturers both at 7.6\%, Senior Lecturers at 5.6\%, Research Fellows at 2.8\%, and Readers at 2.1\% (See Figure 2). 


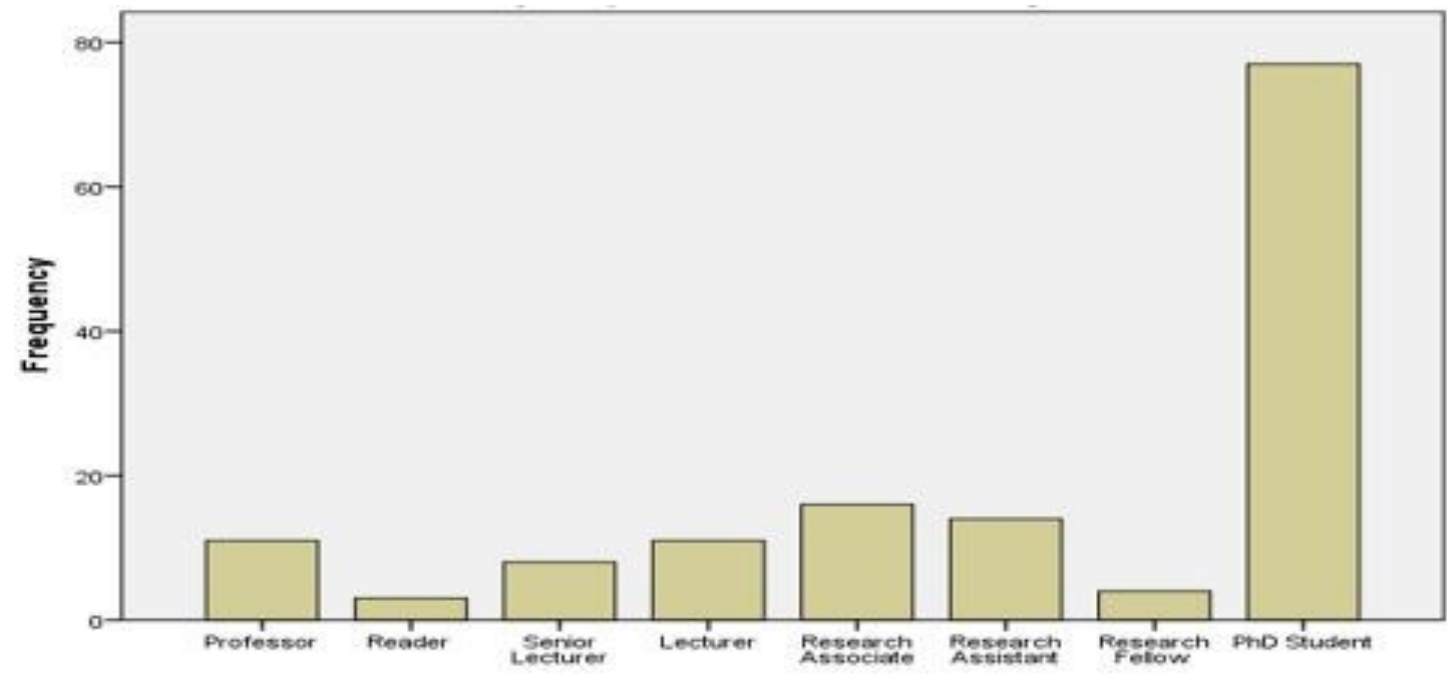

Figure 2: Participants' Positions

Respondents came from the four faculties of the university. Most of them (36.8\%), were from the Faculty of Science, followed by the Faculty of Humanities \& Social Sciences at $25.7 \%$, the Faculty of Engineering at 19.4\%, and Strathclyde Business School at 18.1\% (See Figure 3).

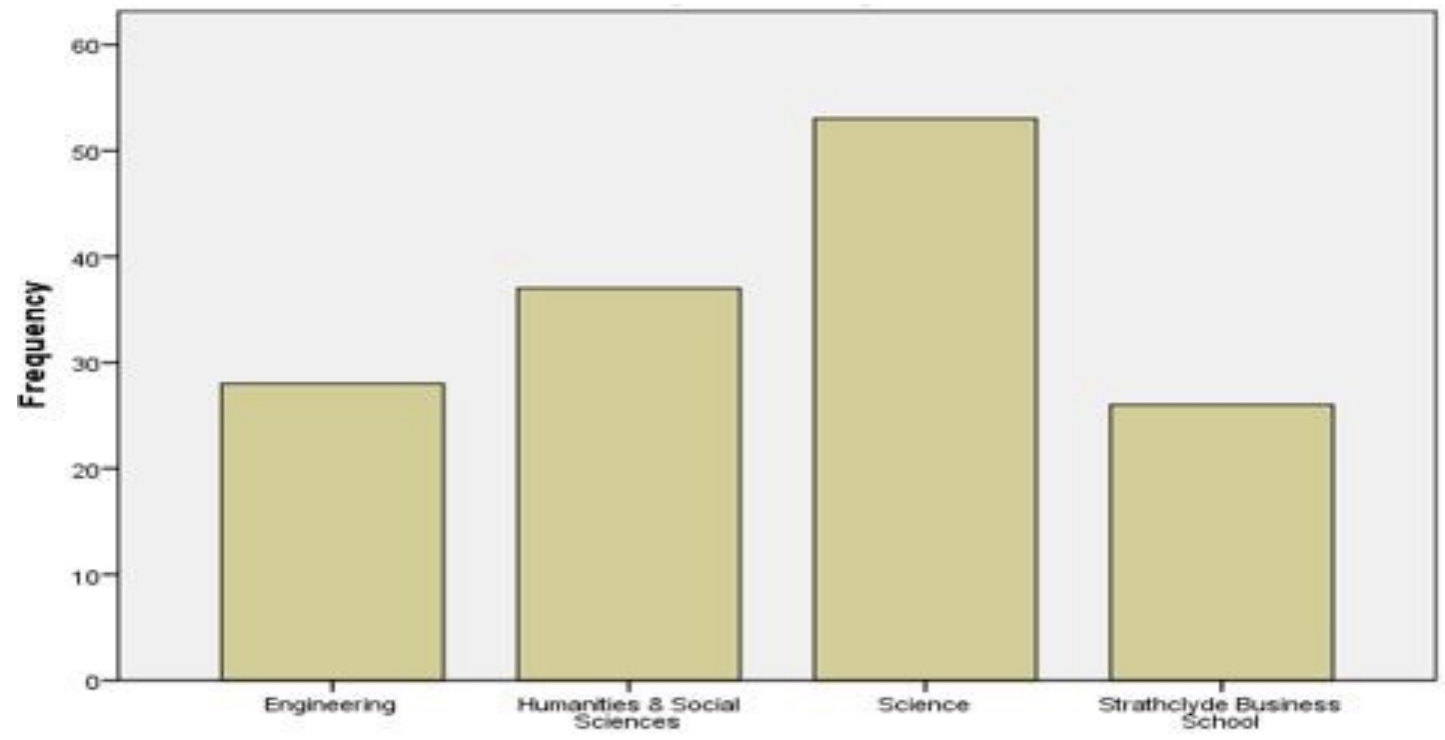

Figure 3: Participants' Faculties

In terms of research experience, $25 \%$ of the respondents had 3-4 years, $22.2 \%$ had 1-2 years, $20.1 \%$ had more than 10 years, $14.6 \%$ had less than 1 year, $10.4 \%$ had $5-6$ years, $4.2 \%$ had 7 8 years, and $3.5 \%$ had $9-10$ years (See Figure 4 ) 


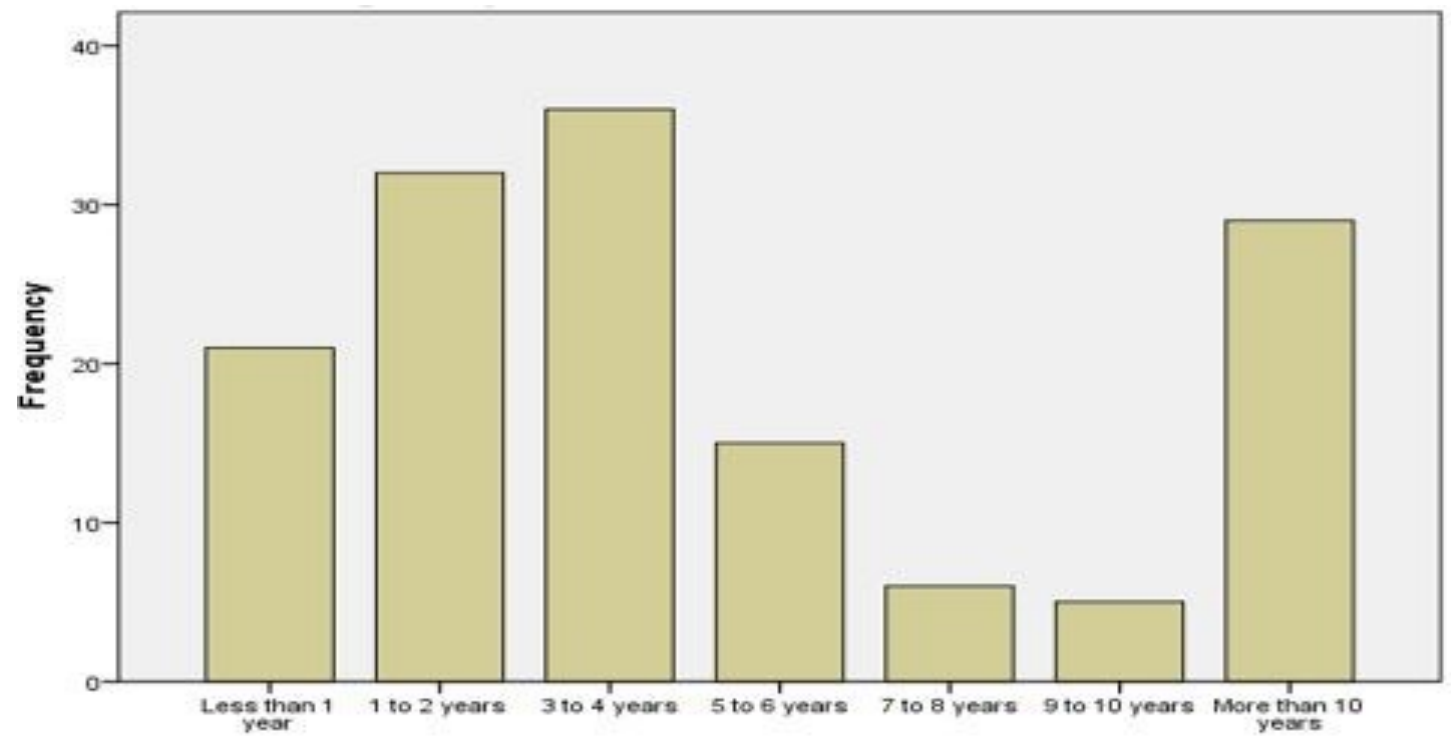

Figure 4: Participants' Experiences

\subsection{Social media and knowledge sharing}

$66 \%$ of respondents reported using social media to share knowledge, while $34 \%$ did not (See Table 1).

Table 1: Number of Participants who use or do not use Social Media for Knowledge Sharing

\begin{tabular}{lccccc}
\hline \multicolumn{1}{c}{ Positions } & Frequency & Use-SM & $\mathbf{\%}$ & Not-Use-SM & \% \\
\hline Professor & 11 & 4 & $3 \%$ & 7 & $5 \%$ \\
Reader & 3 & 1 & $1 \%$ & 2 & $1 \%$ \\
Senior Lecturer & 8 & 5 & $3 \%$ & 3 & $2 \%$ \\
Lecturer & 11 & 9 & $6 \%$ & 2 & $1 \%$ \\
Research & & & & 5 & $3 \%$ \\
Associate & 16 & 11 & $8 \%$ & 4 & $3 \%$ \\
Research Assistant & 14 & 10 & $7 \%$ & 2 & $1 \%$ \\
Research Fellow & 4 & 2 & $1 \%$ & 24 & $17 \%$ \\
PhD Student & 77 & 53 & $37 \%$ & $\mathbf{3 4 \%}$ \\
\hline \multicolumn{1}{c}{ Total } & $\mathbf{1 4 4}$ & $\mathbf{9 5}$ & $\mathbf{6 6 \%}$ & $\mathbf{4 9}$ & \\
\hline
\end{tabular}

Respondents used several types of social media to share knowledge. Figure 5 shows that social networking was the most common type, while microblogging was in second place. Content communities, blogs, and Wikipedia followed these. 


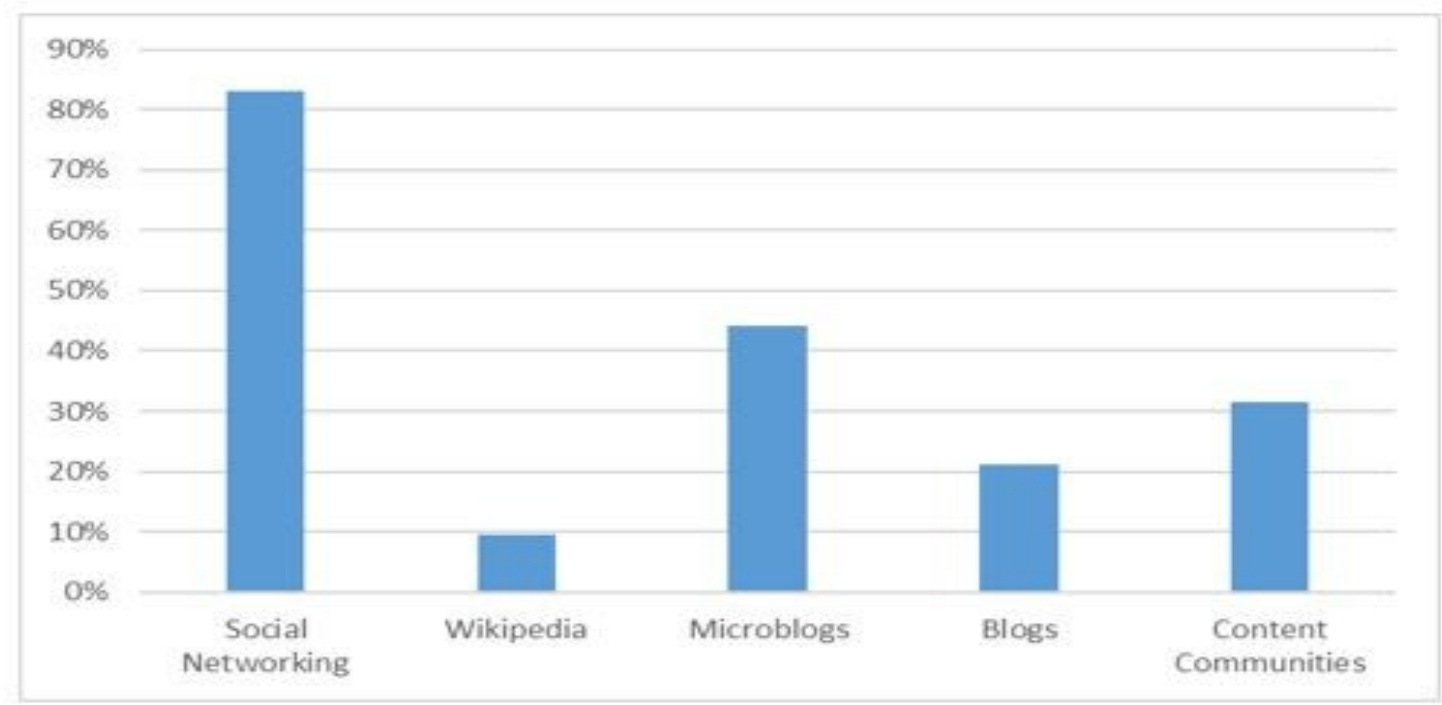

Figure 5: Types of Social Media used by the Participants

Each type incorporates one or more platforms. Thus, Figure 6 presents that most respondents (54\%) use Twitter to share knowledge with others, followed by ResearchGate (47\%), Facebook (42\%), LinkedIn (38\%), Academia.edu (25\%), and WhatsApp (24\%). The least used were Flickr (1\%), Snapchat (5\%), wikis (7\%), Slideshare (9\%), and YouTube and Instagram (13\%).

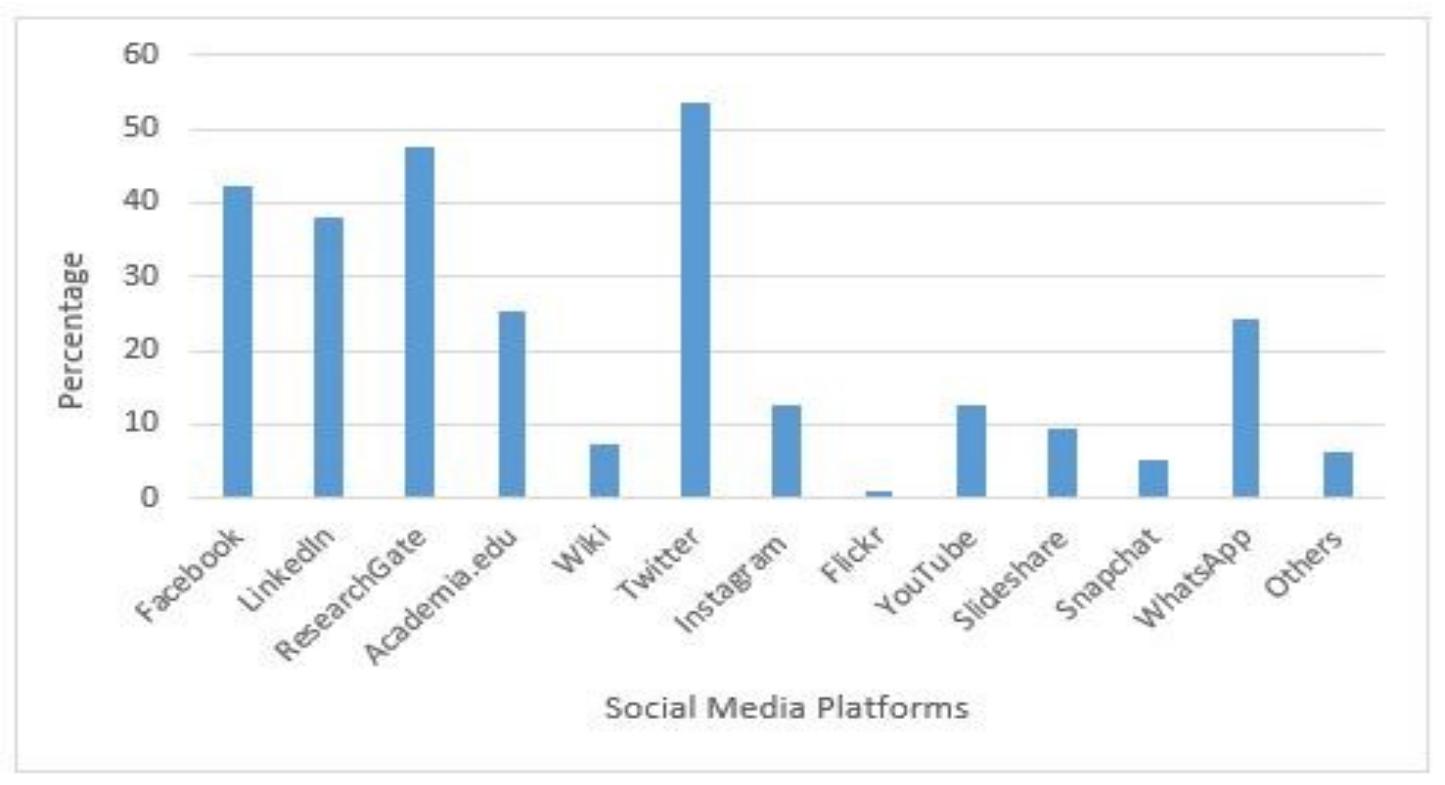

Figure 6: Social Media Platforms used by the Participants

Some participants indicated their use of other platforms not included in the survey such as Pinterest, Vimeo, WordPress, and Reddit.

4.3 Descriptive analysis of the questionnaire 
The questionnaire contains four main sections; each section represents a source of self-efficacy. There are 44 items, which are divided into 22 items for using social media for sharing cognitive experience, and another 22 items for using social media for sharing research outputs.

IBM SPSS was used to calculate mean and standard deviation for each item that related to the 5 -point Likert scale used in the questionnaire $(1=$ Strongly disagree, $2=$ Disagree, $3=$ Neither agree nor disagree, $4=$ Agree, and $5=$ Strongly agree) .

In this study, 95 respondents out of 144 reported using social media for sharing knowledge. 32 used it only to share cognitive experience, six only used it for sharing research outputs, and 57 used it for sharing both types of knowledge. To reduce complexity, the analysis was built around two groups: those who use social media to share cognitive experience $(n=89)$, while and those who share research outputs $(n=63)$.

\subsection{Sources of self-efficacy}

The authors calculated the mean, standard deviation, and percentages for the four sources of self-efficacy for those who shared cognitive experience, and those who shared research outputs. The results appear in the following sub-sections.

\subsubsection{Sharing cognitive experience}

\section{- Personal mastery experience}

Experience with using social media platforms for sharing cognitive experience is an important factor in improving personal mastery experience $(M=3.92, S D=.644)$. Of the 89 participants, $82 \%$ of them agreed or strongly agreed that they have shared cognitive experiences on social media. Only $14.6 \%$ neither agreed nor disagreed, while 3.4\% disagreed.

The second important factor for improving personal mastery experience is skills $(M=3.69, S D$ $=.847) ; 67.5 \%$ of the participants agreed or strongly agreed that they have good skills in the use of social media for sharing their experiences. Only $22.5 \%$ neither agreed nor disagreed, while $10.1 \%$ of the participants disagreed or strongly disagreed.

In third place is confidence $(M=3.60, S D=.808)$. Of the $89,63 \%$ of them agreed or strongly agreed that they feel very confident in using it. Only $10 \%$ disagreed or strongly disagreed, while $27 \%$ neither agreed nor disagreed.

The last factor was attending training courses or workshops to improve their social media ability $(M=1.93, S D=1.064)$. This factor had no strong effect; $77.5 \%$ disagreed or strongly disagreed that they have attended training. Only 13.5\% agreed or strongly agreed, while 9\% neither agreed nor disagreed.

\section{- Vicarious experience}

Two items related to this source were provided in the questionnaire. Observing others' success in using social media to share cognitive experience was an important factor in improving vicarious experience $(M=3.63 ; S D=1.049)$. Of the $89,64 \%$ of them agreed or strongly agreed that they use social media for sharing their experiences because they have seen others' success in using it. Only $19.1 \%$ neither agreed nor disagreed, while $16.9 \%$ disagreed or strongly disagreed.

In second place was seeing colleagues' use of it $(M=3.49$; $S D=1.067)$, where $64 \%$ of the 89 agreed or strongly agreed that they use it because of this Only $16.9 \%$ neither agreed nor disagreed, while $19.1 \%$ disagreed or strongly disagreed. 


\section{- Verbal persuasion}

Encouragement from colleagues was a slightly important factor in sharing cognitive experience $(M=3.16$; $S D=1.127)$. Of the $89,45 \%$ agreed or strongly agreed that they have received encouragement. Some (32.5\%) disagreed or strongly disagreed, while $22.5 \%$ neither agreed nor disagreed.

Receiving encouragement from an institution is less important $(M=2.82 ; S D=1.083)$, where $39.3 \%$ out of 89 participants disagreed or strongly disagreed that they have received encouragement from their institution to use social media for sharing experiences. Moreover, some of these $89(34.8 \%)$ neither agreed nor disagreed, while only $25.8 \%$ agree or strongly agree.

\section{- Emotional arousal}

This source indicated both positive and negative influences. On the positive side, respondents use social media for sharing cognitive experience because they enjoy it $(M=3.72 ; S D=.953)$. Of the $89,70.8 \%$ agree or strongly agree that they enjoy it for sharing their experiences. Only $19.1 \%$ neither agreed nor disagreed, while $10.1 \%$ disagreed or strongly disagreed.

They also use social media for sharing experiences because they have had positive experiences from its use $(M=3.67 ; S D=.750) .67 .5 \%$ out of 89 participants agreed or strongly agreed that they use it because of positive experiences. Only $6.7 \%$ disagreed or strongly disagreed, while $25.8 \%$ neither agreed nor disagreed.

On the negative side, anxiety had effects on respondents' feelings toward it $(M=2.48 ; S D=$ 1.139). $49.4 \%$ disagreed or strongly disagreed that they feel anxious using it, while $29.2 \%$ neither agreed nor disagreed. Some $(21.3 \%)$ agreed or strongly agreed that they feel anxious about it.

Negative experiences are another factor that had effects on respondents' feelings about its use $(M=2.36 ; S D=1.014) .56 .2 \%$ disagreed or strongly disagreed that negative experiences affect their use of social media, while $28.1 \%$ neither agreed nor disagreed. Only $15.7 \%$ agreed that negative experiences affect their use.

According to Table 2, there was only a statistically significant difference in the experience with social media platforms that senior researchers use $(M=4.08, S D=0.616)$ and $\mathrm{PhD}$ students $(\mathrm{M}=3.80, \mathrm{SD}=0.645)$; conditions $\mathrm{t}(87)=2.073, \mathrm{p}=0.041$. 


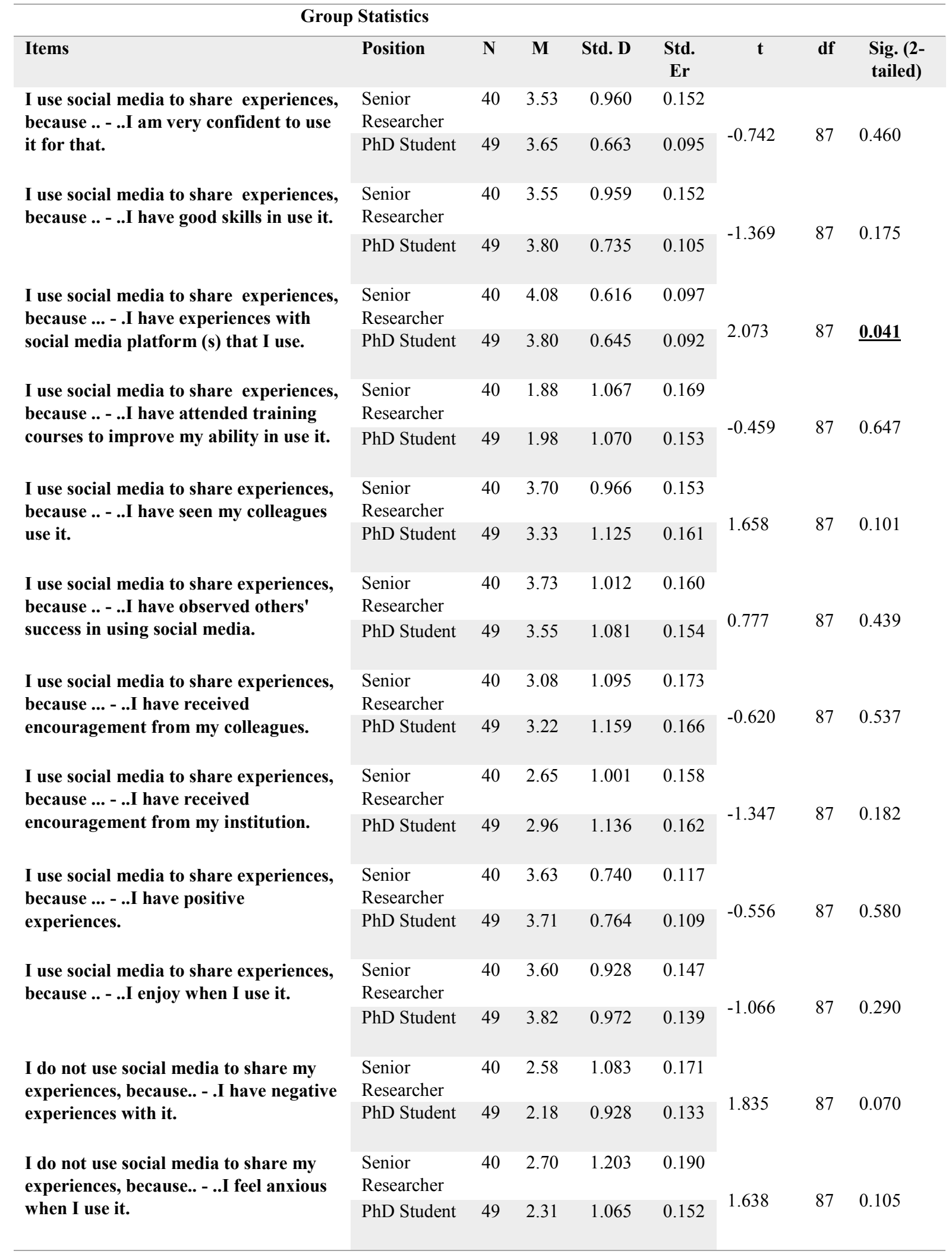




\subsubsection{Sharing research outputs}

\section{- Personal mastery experience}

Experience with using social media platforms to share research outputs is considered the most important factor in improving personal mastery experience $(M=3.95 ; S D=.580)$. Of the 63 participants, $87.3 \%$ agreed or strongly agreed that they had experiences with social media for sharing research outputs. Only $9.5 \%$ neither agreed nor disagreed, while $3.2 \%$ disagreed.

The second most important factor was skills $(M=3.65$; $S D=.845)$, where $68.2 \%$ of the participants agreed or strongly agreed that they have good skills in the use of social media for sharing their research outputs. Only $20.6 \%$ neither agreed nor disagreed, while $11.1 \%$ of the participants disagreed or strongly disagreed.

In third place was confidence in its use for sharing outputs $(M=3.63 ; S D=.885)$. Of the 63 participants, $63.5 \%$ of them agreed or strongly agreed that they are very confident in using it. Only $11.1 \%$ disagreed or strongly disagreed, while $25.4 \%$ neither agreed nor disagreed.

The last factor is attending training courses or workshops to improve ability $(M=2.57 ; S D=$ 1.228). This factor has some effect; $57.1 \%$ disagreed or strongly disagreed that they use social media for sharing research outputs because they have attended training, while $33.4 \%$ agreed or strongly agreed. Only $9 \%$ neither agreed nor disagreed.

\section{- Vicarious experience}

Seeing colleagues use it is slightly more important in improving vicarious experience $(M=3.86$; $S D=.759) .81 \%$ agreed or strongly agreed that they use social media for sharing their experiences because they have seen their colleagues use it. Only $12.7 \%$ neither agreed nor disagreed, while $6.3 \%$ disagreed or strongly disagreed.

In second place is observing others' success $(M=3.84 ; S D=.723) ; 74.6 \%$ agreed or strongly agreed that they use it because they have seen others' success in using it. Only $20.6 \%$ neither agreed nor disagreed, while $4.8 \%$ disagreed.

\section{- Verbal persuasion}

Likewise, for sharing research outputs, receiving encouragement from colleagues is the most important source $(M=3.35 ; S D=1.034)$, where $47.6 \%$ agreed or strongly agreed that they have received this. Some (30.2\%) neither agreed nor disagreed, while $22.2 \%$ disagreed or strongly disagreed.

Encouragement from an institution seems somewhat influential $(M=3.10 ; S D=1.027) ; 36.5 \%$ agreed or strongly agreed that they have received this. $33.3 \%$ neither agreed nor disagreed, while $30.2 \%$ disagreed or strongly disagreed.

\section{- Emotional arousal}

Positive experiences were important for respondents $(M=3.68 ; S D=.758)$. Of the 63 participants, $68.2 \%$ agree or strongly agree that they use it because they have positive experiences with its use. Some participants $(25.4 \%)$ neither agreed nor disagreed, while only $6.4 \%$ disagreed or strongly disagreed. 
They also enjoy using it for sharing their research outputs $(M=3.68 ; S D=.858)$, where $68.2 \%$ agreed or strongly agreed that they enjoy using it for this. Only $8 \%$ disagreed or strongly disagreed, while $23.8 \%$ neither agreed nor disagreed.

Anxiety had effects on respondents' feelings toward sharing research outputs $(M=2.56$; $S D=$ 1.044 ) only $19.1 \%$ agreed or strongly agreed that they felt anxious from its use. More than half $(50.8 \%)$ disagreed or strongly disagreed that they feel anxious from using it, while $30.2 \%$ neither agreed nor disagreed.

Negative experiences had minor effects on respondents' feelings towards its use $(M=2.43$; $S D=.979) .57 .2 \%$ disagreed or strongly disagreed that negative experiences affect their use, while $30.2 \%$ neither agreed nor disagreed. Only $12.7 \%$ agreed or strongly.

According to Table 3, there was no statistically significant difference between senior researchers and $\mathrm{PhD}$ students in the sources of self-efficacy to use social media for sharing research outputs.

\subsection{The impact of the sources of self-efficacy}

\subsubsection{Sharing cognitive experience}

The results of the analysis for the impact of these four sources (Appendix 2) indicated that personal mastery experience is important $(M=3.72$; $S D=.761) .72 \%$ agreed or strongly agreed that if they have confidence, abilities, and skills, they will be keen to use it. Only $6.7 \%$ disagreed, while $21.3 \%$ neither agreed nor disagreed.

$65.1 \%$ agreed or strongly agreed that they would use it more frequently if they have confidence, abilities, and skills. Only $11.2 \%$ disagreed or strongly disagreed, while $23.6 \%$ neither agreed nor disagreed.

The second most important source is emotional arousal $(M=3.70 ; S D=.687)$. Most participants $(79.8 \%)$ agreed or strongly agreed that they would be keen to use it if they have a positive feeling toward its use. Only 3.3\% disagreed or strongly disagreed, while $16.9 \%$ neither agreed nor disagreed. $77.5 \%$ agreed or strongly agreed that they would use it more frequently if they have positive feelings toward its use. Only 3.3\% disagreed or strongly disagreed, while $19.1 \%$ neither agree nor disagree. $65.2 \%$ agreed or strongly agreed that they would not be keen to use it if they have negative feelings toward its use. Some participants (19.1\%) disagreed or strongly disagreed, while $15.7 \%$ neither agreed nor disagreed. $57.3 \%$ agreed or strongly agreed that they would not use it any more if they have negative feelings from its use. Some of the participants $(20.2 \%)$ neither agreed nor disagreed, while $22.5 \%$ disagreed or strongly disagreed.

The third most important source is vicarious experience $(M=3.61 ; S D=.827)$, where $66.3 \%$ of the participants agreed or strongly agreed that they would be keen to use it if they have seen successes from others' use. Only $11.2 \%$ disagreed or strongly disagreed, while $22.5 \%$ neither agreed nor disagreed. Moreover, $65.1 \%$ agreed or strongly agreed that they would use it more frequently if they have seen others' successes, while some of them $(21.3 \%)$ neither agreed nor disagreed. Only $13.5 \%$ disagreed or strongly disagreed that they will use it because of others' successes. 


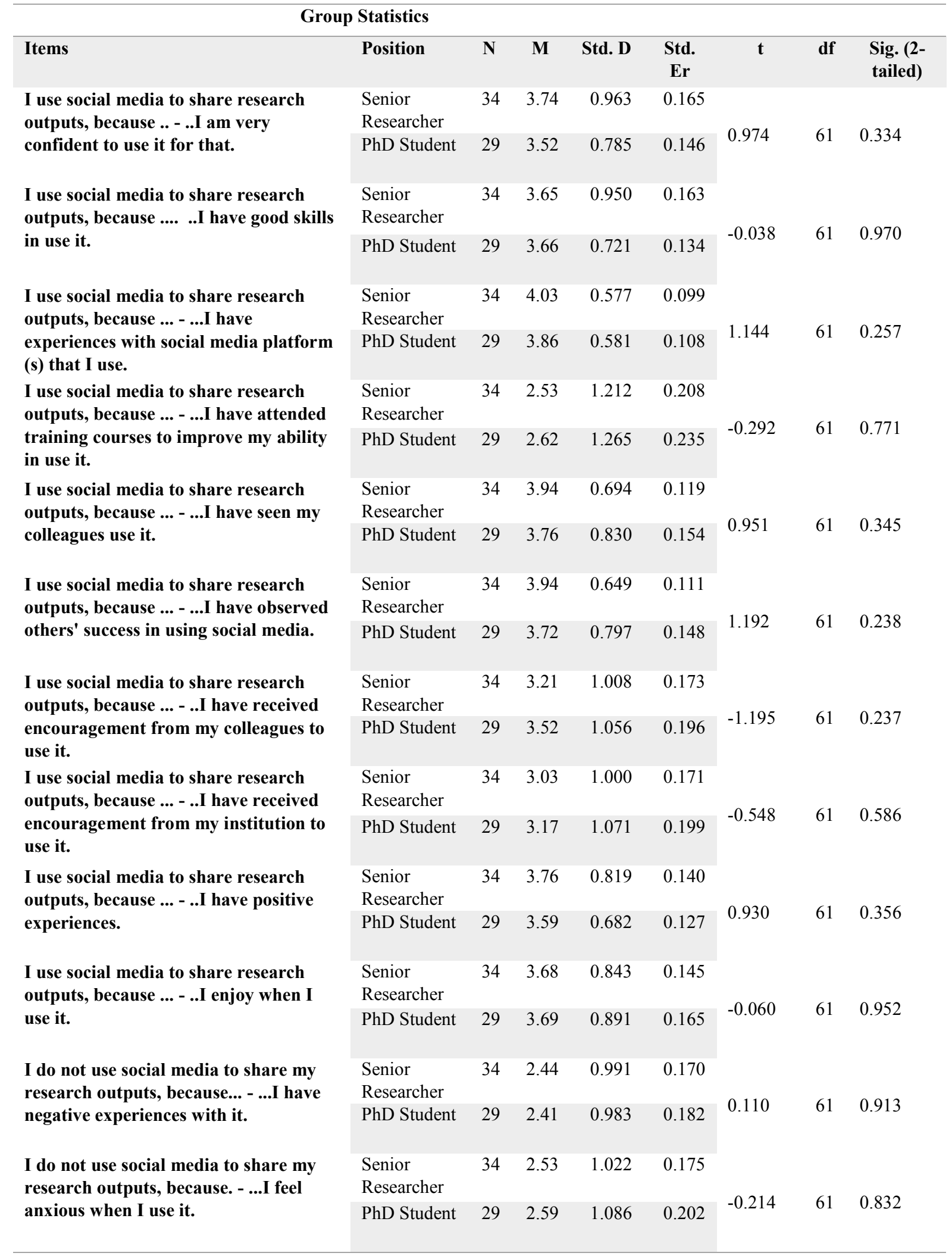

The fourth source is verbal persuasion $(M=3.46 ; S D=.975) .51 .7 \%$ agreed or strongly agreed that they would be keen to use it if they received encouragement continuously, while $33.7 \%$ neither agreed nor disagreed. Only $14.6 \%$ disagreed or strongly disagreed. Furthermore, $52.8 \%$ 
agreed or strongly agreed that they would use it more frequently if they received continuous encouragement towards its use. Some of them (32.6\%) neither agreed nor disagreed, while only $14.6 \%$ disagreed or strongly disagreed.

According to Table 4, there was only a statistically significant difference in the negative feeling from using social media for sharing experience which leads to carelessness in their use from senior researchers $(\mathrm{M}=3.88, \mathrm{SD}=0.853)$ and $\mathrm{PhD}$ students $(\mathrm{M}=3.27, \mathrm{SD}=1.204)$ conditions; $\mathrm{t}(87)=2.697, \mathrm{p}=0.008$.

\subsubsection{Sharing research outputs}

Vicarious experience has more impact on the use of social media to share research outputs $(M$ $=3.90 ; S D=.876$ ). Out of $63,79.3 \%$ agreed or strongly agreed that they would be keen to use it if they have seen successes from others' use. Only $7.9 \%$ disagreed or strongly disagreed, while $12.7 \%$ neither agree nor disagree. Moreover, $76.2 \%$ agreed or strongly agreed that they would use it more frequently if they have seen others' successes. Only 9.5\% disagreed or strongly disagreed that they will use it because of others' successes, while $14.3 \%$ neither agreed nor disagreed.

The second important source is personal mastery experience $(M=3.87 ; S D=.789)$. Of the 63 , $74.6 \%$ agreed or strongly agreed that if they have confidence, abilities, and skills, they would be keen to use it. Only $6.4 \%$ disagreed or strongly disagreed, while $19 \%$ neither agreed nor disagreed. Moreover, $73 \%$ agreed or strongly agreed that they will use it more frequently if they have confidence, abilities, and skills. Only $3.2 \%$ disagreed or strongly disagreed, while some of these participants $(23.6 \%)$ neither agreed nor disagreed.

The third source is emotional arousal $(M=3.75$; $S D=.563)$. The majority $(90.5 \%)$ agree or strongly agree that they would be keen to use it if they have positive feelings toward this use. Only $1.6 \%$ disagreed, while only $7.9 \%$ neither agreed nor disagreed. $87.3 \%$ agreed or strongly agreed that they will use it more frequently if they have positive feelings toward its use. Only $1.6 \%$ disagreed, while $11.1 \%$ neither agreed nor disagreed. With regard to negative feelings, $68.2 \%$ agreed or strongly agreed that they would not be keen to use it if they have negative feelings toward its use. Some participants $(14.2 \%)$ disagreed or strongly disagreed, while $17.5 \%$ neither agreed nor disagreed. $58.8 \%$ agreed or strongly agreed that they would not use it anymore if they had negative feelings from its use. Some of the participants $(22.2 \%)$ neither agreed nor disagreed, while 19\% disagreed or strongly disagreed.

The fourth and last important source of self-efficacy for using social media to share research outputs is verbal persuasion $(M=3.72 ; S D=.883)$. $65.1 \%$ agreed or strongly agreed that they would be keen to use social media for sharing their research outputs if they receive encouragement continuously, while $25.4 \%$ neither agreed nor disagreed. Only $9.5 \%$ disagreed or strongly disagreed with this point. $68.3 \%$ agree or strongly agree that they would use it more frequently if they receive continuous encouragement towards its use. Some (22.2\%) neither agreed nor disagreed, while only $9.5 \%$ disagreed or strongly disagreed. 


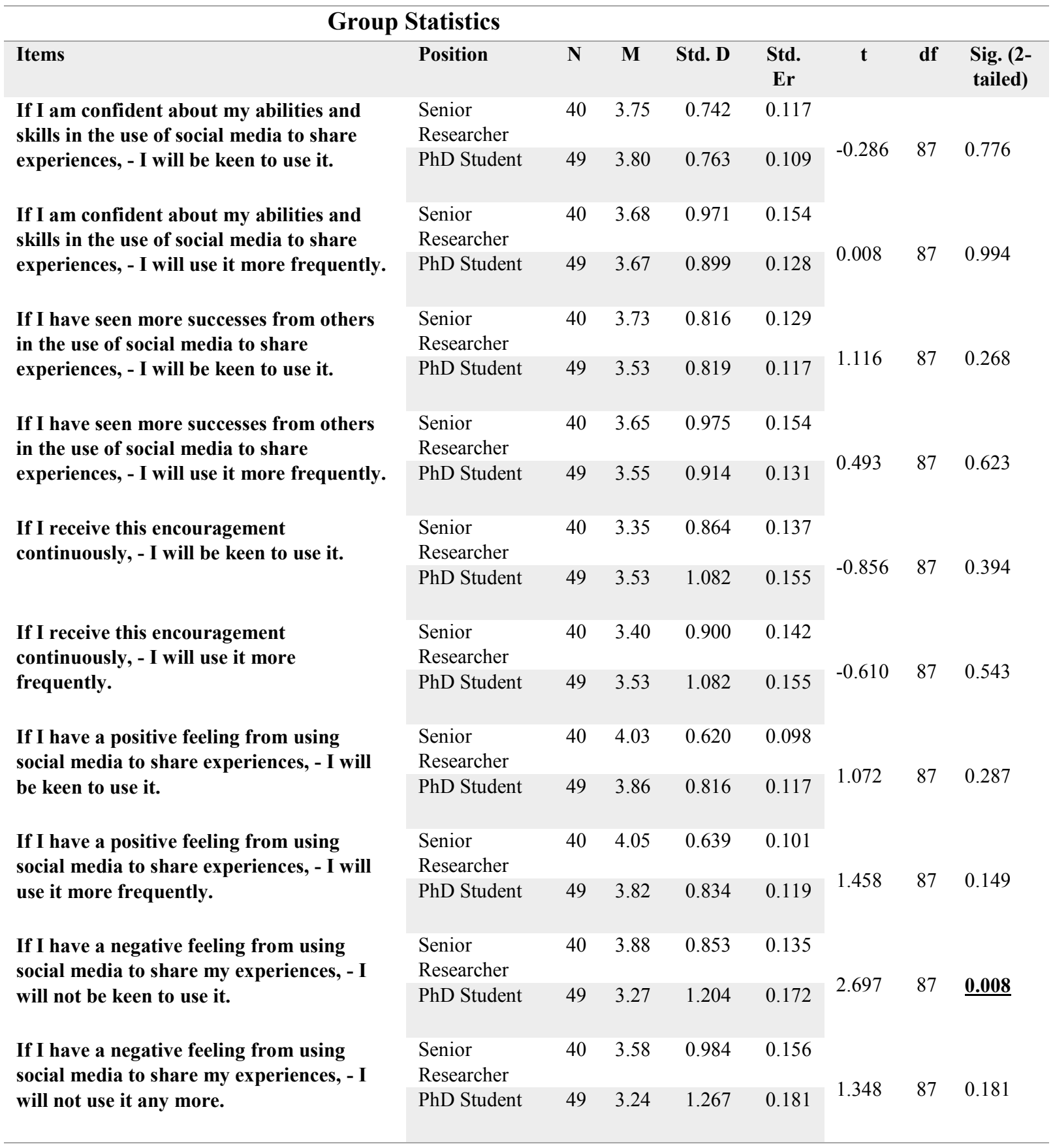

With regard to the impact of sources of self-efficacy, as shown in Table 5, there was a statistically significant difference in the impact of encouragement to make senior researchers $(\mathrm{M}=3.44, \mathrm{SD}=0.824)$ and $\mathrm{PhD}$ students $(\mathrm{M}=4.03, \mathrm{SD}=0.906)$ keen to use it with conditions; $\mathrm{t}(61)=-2.722, \mathrm{p}=0.008$. Also, there was a statistically significant difference in the impact of encouragement to make senior researchers $(\mathrm{M}=3.41, \mathrm{SD}=0.783)$ and $\mathrm{PhD}$ students $(\mathrm{M}=4.10$, $\mathrm{SD}=0.860)$ use it more frequently with conditions; $\mathrm{t}(61)=-3.341, \mathrm{p}=0.001$. There was a statistically significant difference between senior researchers $(\mathrm{M}=3.59, \mathrm{SD}=0.821)$ and $\mathrm{PhD}$ students $(\mathrm{M}=3.07, \mathrm{SD}=1.132)$ in negative feelings that could prevent them from using social media for sharing research outputs with conditions; $t(61)=2.105, p=0.039$. 
Table 5: Results of Independent T tests for the impact of Sources of self-efficacy for sharing research outputs via social media

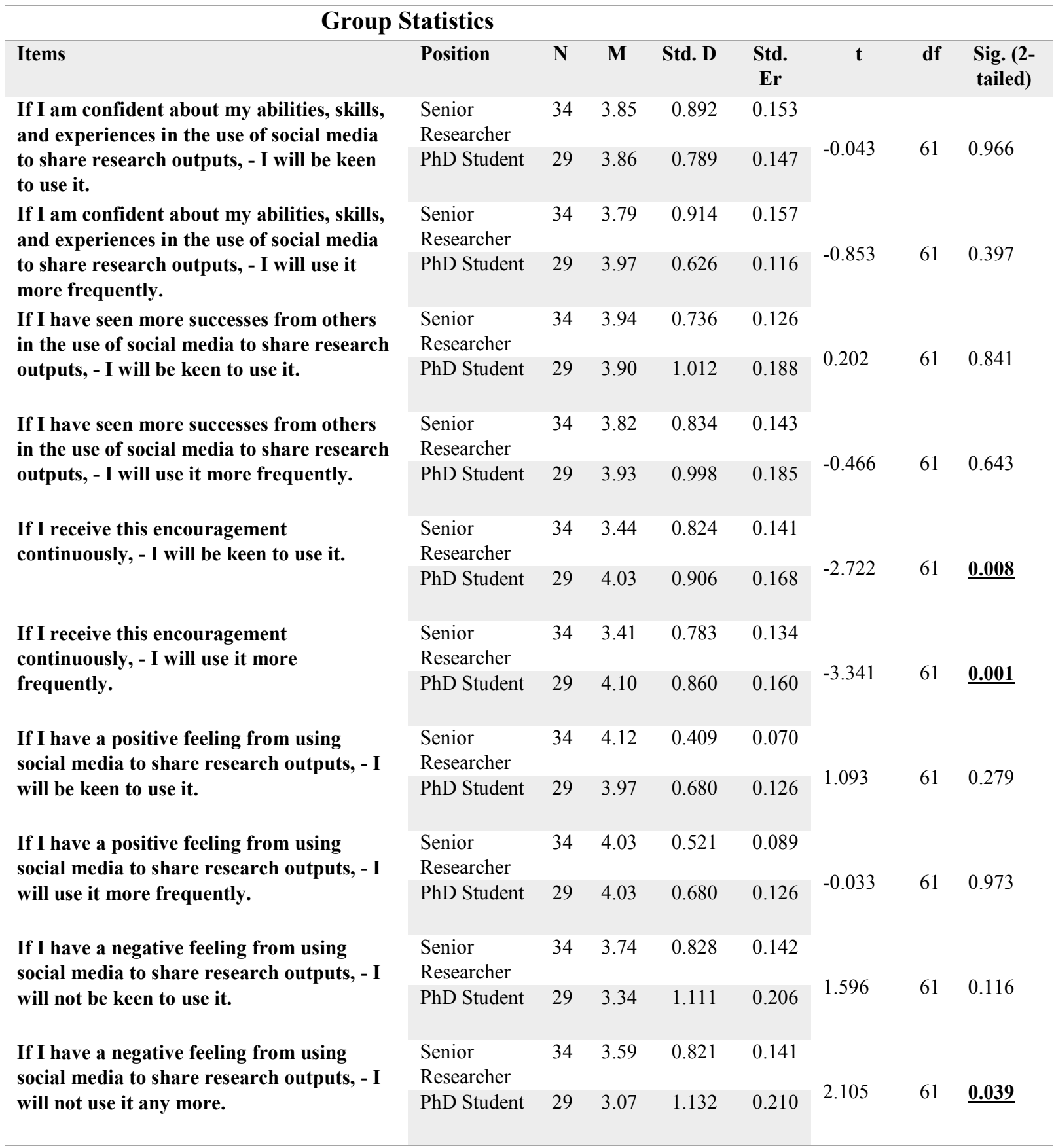

\subsection{Barriers to using social media for knowledge sharing}

According to Table 1, 49 respondents do not use social media to share knowledge with others; several barriers prevented them from its use. Table 6 shows that $14 \%$ out of 49 do not use it because they have not seen anyone use it successfully, while $8 \%$ of them do not see the benefits from its use. Moreover, $6 \%$ of these participants do not like to use it, and $4 \%$ have had negative experiences with it. 


\begin{tabular}{lccc}
\hline Barriers & $\boldsymbol{N}$ & Frequency & Percent \\
\hline I do not like social media & 49 & 3 & 6 \\
I do not see the benefit of using social media & 49 & 4 & 8 \\
I have had negative experiences with social media & 49 & 2 & 4 \\
I have not seen anyone successfully use social & 49 & 7 & 14 \\
media & 49 & 9 & 18 \\
Others & & 9 & \\
\hline
\end{tabular}

However, nine out of those 49 participants added some other barriers from their perspectives. Table 7 indicates that $56 \%$ of them have a lack of experience, while $44 \%$ have negative feelings from its use.

Table 7: Other Barriers of the use of social media

\begin{tabular}{lccc}
\hline Other Barriers & N & Frequency & Percent \\
\hline Lack of experience & 9 & 5 & 56 \\
Negative emotions & 9 & 4 & 44 \\
\hline
\end{tabular}

\section{Discussion and Conclusion}

\subsection{Sources of self-efficacy}

This study contributes to existing literature by investigating sources of self-efficacy that researchers rely on for using social media to share knowledge and their impact on this use. Sources of self-efficacy and their impact have not been addressed comprehensively in an online context. According to the findings of this study, participants relied on these sources to influence their use of social media to share knowledge. They may draw upon one source more than others. Based on these results, it seems possible that finding ways to increase self-efficacy through these sources could increase use in those that do not use it often. These results supported the previous qualitative phase of this study (Alshahrani \& Rasmussen Pennington, 2018).

Participants relied on their experience and skills in the use of social media for sharing knowledge. This finding corroborates the theoretical framework of Bandura $(1977 ; 1986$; 1997), in which he suggested that personal mastery experience is the most important and influential source of self-efficacy. It also aligns with other studies such as Zeldin, Britner, and Pajares (2008) and Hendricks (2016), which identified personal mastery experience as the most influential source. Indeed, personal mastery experience can also influence other sources, because it must be developed before drawing on the others. Experience can be gained through practice, training, and mentoring, which are the main processes in developing self-efficacy. This account agrees with Bandura (2004b). However, practice and frequent use are the most utilized ways of promoting personal mastery experience to support the use of social media for knowledge sharing, while training is less utilized. In fact, due to the frequent use, their capabilities and skills in social media are enhanced, thus building their self-efficacy in its use for knowledge sharing. 
Given the importance of personal mastery experience, the importance of training for improving researchers' skills and abilities cannot be ignored. It can allow researchers to understand the benefits and risks of using social media as well as its features and opportunities, which can lead them to use it more effectively (Bizzi, 2018). Therefore, researchers need to attend workshops and training programs on how to use it and gain its benefits in order to improve their capabilities and skills. They also need to practise using it more frequently in order to increase their mastery experience, which will lead to enhancing their self-efficacy. Within academic institutions, those who use social media effectively and extensively could be asked to provide training for others. These programs can show researchers how to use these media professionally and obtain the potential benefits from such use. They may then attempt to follow their instructors in this use and choose them as role models. This will help newer users build self-efficacy.

Vicarious experience is another significant source. These findings are in line with Bandura (1977; 1986; 1997), Zeldin et al. (2008), Surland (2010), and Hendricks (2016), whose studies established that observing and seeing others perform a task successfully may increase individuals' confidence in their own ability to perform the same thing. Seeing the successful performance of colleagues could lead researchers to believe that they themselves possess the capabilities to use social media successfully as well. Thus, those colleagues become role models, enabling them to build their own self-efficacy with the tools. As stated above, however, researchers may not benefit from vicarious experience unless they have sufficient skills and abilities to use social media. Also, the chosen role models should be those who use social media actively and effectively for sharing knowledge.

Verbal persuasion was another source of self-efficacy. The findings of this study are consistent with those of Bandura (1977; 1986; 1997), Garlin and McGuiggan (2002), Zeldin et al. (2008), Surland (2010), and Hendricks (2016), which argued that encouragement from others may motivate individuals to perform effectively. Thus, researchers can be convinced by their colleagues to use social media to spread their cognitive experience and research outputs and achieve greater impact. Those researchers who use social media successfully could tell other researchers about their success and beneficial use in order to encourage other researchers to use it as well. Researchers can also be motivated by following role models, as mentioned previously; seeing others' use of social media can provide significant motivation and this may indirectly encourage them to use these media. Another source of encouragement is institutions, which can convince researchers to utilize social media to increase institutional and personal visibility, which could help recruit other researchers and new students. Institutional recognition can be achieved by showing others its knowledge production and other academic achievements, which in turn will increase its reputation and impact. Nowadays, the most effective way to present these outputs is via social media, so institutions are naturally keen to encourage their researchers and staff to use it. This encouragement may take several forms, such as organizing workshops and training or providing tangible or intangible rewards for success. This can also help to improve the researchers' self-efficacy in such use. However, like vicarious experience, verbal persuasion should follow personal mastery experience for maximum effectiveness; this aligns with findings in Warner et al. (2014) and Wise and Trunnell (2001).

Emotional arousal consists of psychological reactions based on researchers' positive and negative experiences of social media use. Positive emotion can motivate researchers to use it, whereas negative feelings can prevent it. The two phases of this study indicated that positive experiences and feelings (e.g. enjoyment) might encourage more frequent use, which naturally then can lead to an improvement in self-efficacy. On the other hand, negative experiences and 
feelings (e.g. anxiety) might prevent them from using it temporarily, if not completely. The effect is a decrease in self-efficacy. This finding is in agreement with previous work from Bandura (1977; 1986; 1997), Wise and Trunnell (2001), Garlin and McGuiggan (2002), and Hendricks (2016). Indeed, positive or negative emotional arousal can leave individuals with a high or low perception, respectively, of their ability to persist in a task. This source can also influence other sources of self-efficacy. Researchers should keep in mind that others' negative reactions on social media are part and parcel of online discussion, and should not let this discourage them from further online interaction. Negative reactions should rather be viewed as learning experiences.

According to these results, the lack of self-efficacy and ignorance of its sources can be the main barriers for social media use. This is consistent with Bandura (1977) about the role of these sources for improving self-efficacy. Therefore, these sources need more research, development, and practical implementation.

\subsection{Implications and future research}

This is likely the first study to investigate these sources and their impact on researchers' use of social media to share knowledge. Therefore, this study has made a new contribution to the existing literature of social media and knowledge sharing.

Researchers need to improve their skills and abilities for using social media to share knowledge. This can be accomplished, for example, by attending training sessions and practicing its use frequently in order to build self-efficacy. They also need to control their emotions (especially negative ones), which also can lead to improved self-efficacy. Colleagues who use social media effectively and institutions should support less active users to engage with it through verbal persuasion and role modelling. Building and developing these sources could have an effective role in motivating less active social media users to increase their activity.

This study brings information scientists and knowledge managers to the attention of a new direction for research. It could be replicated at multiple institutions to obtain more understanding and insights. Moreover, different methods for collecting and analysing data could be used for additional triangulation. There is also a need for empirical studies to investigate these sources and their comparative impact on sharing both tacit and explicit knowledge.

\section{References}

Alshahrani, H., \& Rasmussen Pennington, D. (2018). "Why not use it more?" Sources of selfefficacy in researchers' use of social media for knowledge sharing. Journal of Documentation, 74(6), 1274-1292.

Al-Taee, M. L. (2014). The role of social networking tools in facilitating knowledge management and sharing processes at the UAE municipalities: opportunities and challenges. (Doctor of philosophy), University of Birmingham.

Askar, P., \& Davenport, D. (2009). An investigation of factors related to self-efficacy for java programming among engineering students. TOJET: The Turkish Online Journal of Educational Technology, 8(1).

Bandura, A. (1977). Self-efficacy: toward a unifying theory of behavioral change. Psychological review, 84(2), 191. 
Bandura, A. (1982). Self-efficacy mechanism in human agency. American psychologist, 37(2), 122.

Bandura, A. (1986). Social foundations of thought and action: A social cognitive theory: Prentice-Hall, Inc.

Bandura, A. (1994). Self- efficacy: Wiley Online Library.

Becerra-Fernandez, I., \& Sabherwal, R. (2014). Knowledge management: Systems and processes: Routledge.

Bilgihan, A., Barreda, A., Okumus, F., \& Nusair, K. (2016). Consumer perception of knowledge-sharing in travel-related Online Social Networks. Tourism Management, 52, 287-296.

Brown, S. A., Dennis, A. R., Burley, D., \& Arling, P. (2013). Knowledge sharing and knowledge management system avoidance: The role of knowledge type and the social network in bypassing an organizational knowledge management system. Journal of the American Society for Information Science and Technology, 64(10), 2013-2023. doi:10.1002/asi.22892

Bryman, A. (2012). Social Research Methods: Oxford University Press.

Bukowitz, W. R., \& Williams, R. L. (2000). The knowledge management fieldbook: Financial Times/Prentice Hall.

Carrigan, M. (2016). Social media for academics: Sage.

Celik, V., \& Yesilyurt, E. (2013). Attitudes to technology, perceived computer self-efficacy and computer anxiety as predictors of computer supported education. Computers \& Education, 60(1), 148-158. doi:http://dx.doi.org/10.1016/j.compedu.2012.06.008

Cheung, C. M. K., Lee, M. K. O., \& Lee, Z. W. Y. (2013). Understanding the continuance intention of knowledge sharing in online communities of practice through the postknowledge-sharing evaluation processes. Journal of the American Society for Information Science and Technology, 64(7), 1357-1374. doi:10.1002/asi.22854

Cho, H., Chen, M., \& Chung, S. (2010). Testing an integrative theoretical model of knowledgesharing behavior in the context of Wikipedia. Journal of the American Society for Information Science and Technology, 61(6), 1198-1212. doi:10.1002/asi.21316

Chow, W. S., \& Chan, L. S. (2008). Social network, social trust and shared goals in organizational knowledge sharing. Information \& Management, 45(7), 458-465.

Cliff, M. A., \& King, M. C. (1996). A proposed approach for evaluating expert wine judge performance using descriptive statistics. Journal of Wine Research, 7(2), 83-90.

Collins, H. (2010). Tacit and explicit knowledge: University of Chicago Press.

Connelly, C. E., \& Kelloway, K. E. (2003). Predictors of employees' perceptions of knowledge sharing cultures. Leadership \& Organization Development Journal, 24(5), 294-301.

Cottrell, R. R., \& McKenzie, J. F. (2010). Health promotion and education research methods: Using the five-chapter thesis/dissertation model: Jones \& Bartlett Publishers.

Creswell, J. W. (2014). Research Design-Qualitative, Quantitative \& Mixed methods approaches. 4: e upplagan) SAGE Publications: Inc.

DeVellis, R. F. (2016). Scale development: Theory and applications (Vol. 26): Sage publications.

Edwards, D., Cheng, M., Wong, I. A., Zhang, J., \& Wu, Q. (2017). Ambassadors of knowledge sharing: Co-produced travel information through tourist-local social media exchange. International Journal of Contemporary Hospitality Management, 29(2), 690-708. doi:doi:10.1108/IJCHM-10-2015-0607

Eid, M. I., \& Al-Jabri, I. M. (2016). Social networking, knowledge sharing, and student learning: The case of university students. Computers \& Education, 99, 14-27. 
Ellison, N. B., Gibbs, J. L., \& Weber, M. S. (2015). The use of enterprise social network sites for knowledge sharing in distributed organizations: The role of organizational affordances. American Behavioral Scientist, 59(1), 103-123.

Evans, J. R., \& Mathur, A. (2005). The value of online surveys. Internet research, 15(2), 195219.

Fisher, M. J., \& Marshall, A. P. (2009). Understanding descriptive statistics. Australian Critical Care, 22(2), 93-97.

Fotis, J. N. (2015). The Use of social media and its impacts on consumer behaviour: the context of holiday travel. (Doctor of philosophy), Bournemouth University.

Frey, B. (2006). Statistics hacks: Tips \& tools for measuring the World and beating the odds: " O'Reilly Media, Inc.".

Gegenfurtner, A., Veermans, K., \& Vauras, M. (2013). Effects of computer support, collaboration, and time lag on performance self-efficacy and transfer of training: A longitudinal meta-analysis. Educational Research Review, 8, 75-89. doi:http://dx.doi.org/10.1016/j.edurev.2012.04.001

Greifeneder, E., Pontis, S., Blandford, A., Attalla, H., Neal, D., \& Schlebbe, K. (2018). Researchers' attitudes towards the use of social networking sites. Journal of Documentation, 74(1), 119-136.

Harlow, A. (2010). Online surveys - possibilities, pitfalls and practicalities: The experience of the TELA evaluation. Waikato Journal of Education, 15(2).

Hendricks, K. S. (2016). The sources of self-efficacy: Educational research and implications for music. Update: Applications of Research in Music Education, 35(1), 32-38.

Jabr, N. H. (2011). Social networking as a tool for extending academic learning and communication. International Journal of Business and Social Science, 2(12).

Jolaee, A., Md Nor, K., Khani, N., \& Md Yusoff, R. (2014). Factors affecting knowledge sharing intention among academic staff. International Journal of Educational Management, 28(4), 413-431.

Kaplan, A. M., \& Haenlein, M. (2010). Users of the world, unite! The challenges and opportunities of Social Media. Business horizons, 53(1), 59-68.

Kothari, A., Rudman, D., Dobbins, M., Rouse, M., Sibbald, S., \& Edwards, N. (2012). The use of tacit and explicit knowledge in public health: a qualitative study. Implementation Science, 7(1), 1.

Kwahk, K.-Y., \& Park, D.-H. (2016). The effects of network sharing on knowledge-sharing activities and job performance in enterprise social media environments. Computers in Human Behavior, 55, 826-839.

Lee, J.-N. (2001). The impact of knowledge sharing, organizational capability and partnership quality on IS outsourcing success. Information \& Management, 38(5), 323-335. doi:http://dx.doi.org/10.1016/S0378-7206(00)00074-4

Ma, L., Lee, C. S., \& Goh, D. H.-L. (2014). Understanding news sharing in social media: An explanation from the diffusion of innovations theory. Online Information Review, 38(5), 598-615. doi:doi:10.1108/OIR-10-2013-0239

Muijs, D. (2011). Doing quantitative research in education with SPSS: Sage.

Nonaka, I., \& Von Krogh, G. (2009). Perspective-tacit knowledge and knowledge conversion: Controversy and advancement in organizational knowledge creation theory. Organization science, 20(3), 635-652.

Oh, S., \& Syn, S. Y. (2015). Motivations for sharing information and social support in social media: A comparative analysis of Facebook, Twitter, Delicious, YouTube, and Flickr. Journal of the Association for Information Science and Technology, 66(10), 2045-2060. doi:10.1002/asi.23320 
Pajares, F., \& Kranzler, J. (1994). Self-efficacy, self-concept, and general mental ability in mathematical problem-solving. Florida educational research council research bulletin, 26(1/2), 8-32.

Pajares, F., \& Miller, M. D. (1994). Role of self-efficacy and self-concept beliefs in mathematical problem solving: A path analysis. Journal of educational psychology, 86(2), 193.

Pajares, F., \& Miller, M. D. (1995). Mathematics self-efficacy and mathematics performances: The need for specificity of assessment. Journal of counseling psychology, 42(2), 190.

Pallant, J. (2013). SPSS survival manual: McGraw-Hill Education (UK).

Panahi, S. (2014). Social media and tacit knowledge sharing: physicians' perspectives and experiences. (Doctor of Philosophy), Queensland University of Technology.

Panahi, S., Watson, J., \& Partridge, H. (2012a). Potentials of social media for tacit knowledge sharing amongst physicians: preliminary findings. Paper presented at the Proceedings of the 23rd Australasian Conference on Information Systems, ACIS 2012, Australia.

Panahi, S., Watson, J., \& Partridge, H. (2012b). Social media and tacit knowledge sharing: Developing a conceptual model. World Academy of Science, Engineering and Technology(64), 1095-1102.

Panahi, S., Watson, J., \& Partridge, H. (2016). Conceptualising social media support for tacit knowledge sharing: physicians' perspectives and experiences. Journal of Knowledge Management, 20(2), 344-363. doi:doi:10.1108/JKM-06-2015-0229

Papadopoulos, T., Stamati, T., \& Nopparuch, P. (2013). Exploring the determinants of knowledge sharing via employee weblogs. International Journal of Information Management, 33(1), 133-146.

Pickard, A. J. (2013). Research methods in information: Facet publishing.

Polyani, M. (1966). The tacit dimension. Peter Smith, Gloucester, Mass.

Razmerita, L., Kirchner, K., \& Nabeth, T. (2014). Social media in organizations: leveraging personal and collective knowledge processes. Journal of Organizational Computing and Electronic Commerce, 24(1), 74-93.

Šajeva, S. (2014). Encouraging knowledge sharing among employees: how reward matters. Procedia-Social and Behavioral Sciences, 156, 130-134.

Srivastava, A., Bartol, K. M., \& Locke, E. A. (2006). Empowering leadership in management teams: Effects on knowledge sharing, efficacy, and performance. Academy of Management Journal, 49(6), 1239-1251.

Tschannen-Moran, M., \& McMaster, P. (2009). Sources of self-efficacy: Four professional development formats and their relationship to self-efficacy and implementation of a new teaching strategy. The Elementary School Journal, 110(2), 228-245.

Van Selm, M., \& Jankowski, N. W. (2006). Conducting online surveys. Quality and quantity, $40(3), 435-456$.

Veletsianos, G. (2016). Social Media in Academia: Networked Scholars: Routledge.

Veletsianos, G. (2017). Toward a generalizable understanding of Twitter and social media use across MOOCs: who participates on MOOC hashtags and in what ways? Journal of Computing in Higher Education, 29(1), 65-80.

Vuori, V., \& Okkonen, J. (2012). Knowledge sharing motivational factors of using an intraorganizational social media platform. Journal of Knowledge Management, 16(4), 592603.

Wiedenbeck, S. (2005). Factors affecting the success of non-majors in learning to program. Paper presented at the Proceedings of the first international workshop on Computing education research. 
Wiedenbeck, S., Labelle, D., \& Kain, V. N. (2004). Factors affecting course outcomes in introductory programming. Paper presented at the 16th Annual Workshop of the Psychology of Programming Interest Group.

Zawawi, A. A., Zakaria, Z., Kamarunzaman, N. Z., Noordin, N., Sawal, M. Z. H. M., Junos, N. M., \& Najid, N. S. A. (2011). The study of barrier factors in knowledge sharing: a case study in public university. Management Science and Engineering, 5(1), 59. 


\begin{tabular}{|c|c|c|c|c|c|c|c|c|c|}
\hline \multicolumn{10}{|c|}{ Appendix 1: Questionnaire's items and descriptive statistics (Sources of self-efficacy) } \\
\hline Variables & & Items & Mean & SD & 1 & 2 & 3 & 4 & 5 \\
\hline \multirow{4}{*}{$\begin{array}{l}\text { Personal Master } \\
\text { Experiences } \\
\text { (Sharing } \\
\text { experiences) }\end{array}$} & PMSE1 & $\begin{array}{l}\text { I am very confident to use social media for } \\
\text { sharing experiences. }\end{array}$ & 3.60 & 0.808 & 1.1 & 9.0 & 27.0 & 55.1 & 7.9 \\
\hline & PMSE2 & $\begin{array}{l}\text { I have good skills in use social media for sharing } \\
\text { experiences. }\end{array}$ & 3.69 & 0.847 & 1.1 & 9.0 & 22.5 & 55.1 & 12.4 \\
\hline & PMSE3 & $\begin{array}{l}\text { I have experiences with social media platform (s) } \\
\text { that I use for Sharing experiences. }\end{array}$ & 3.92 & 0.644 & 0.0 & 3.4 & 14.6 & 68.5 & 13.5 \\
\hline & PMSE4 & $\begin{array}{l}\text { I have attended training courses to improve my } \\
\text { ability in use social media for sharing } \\
\text { experiences. }\end{array}$ & 1.93 & 1.064 & 43.8 & 33.7 & 9.0 & 12.4 & 1.1 \\
\hline \multirow{4}{*}{$\begin{array}{l}\text { Vicarious } \\
\text { Experience } \\
\text { (Sharing } \\
\text { experiences) } \\
\text { Verbal Persuasion } \\
\text { (Sharing } \\
\text { experiences) }\end{array}$} & VESE1 & $\begin{array}{l}\text { I have seen my colleagues use social media for } \\
\text { sharing experiences. }\end{array}$ & 3.49 & 1.067 & 6.7 & 12.4 & 16.9 & 52.8 & 11.2 \\
\hline & VESE2 & $\begin{array}{l}\text { I have observed others' success in using social } \\
\text { media for sharing experiences. }\end{array}$ & 3.63 & 1.049 & 3.4 & 13.5 & 19.1 & 44.9 & 19.1 \\
\hline & VPSE1 & $\begin{array}{l}\text { I have received encouragement from my } \\
\text { colleagues to use social media for sharing } \\
\text { experiences. }\end{array}$ & 3.16 & 1.127 & 6.7 & 25.8 & 22.5 & 34.8 & 10.1 \\
\hline & VPSE2 & $\begin{array}{l}\text { I have received encouragement from my } \\
\text { institution to use social media for sharing } \\
\text { experiences. }\end{array}$ & 2.82 & 1.083 & 11.2 & 28.1 & 34.8 & 19.1 & 6.7 \\
\hline \multirow{4}{*}{$\begin{array}{l}\text { Emotional } \\
\text { Arousal (Sharing } \\
\text { experiences) }\end{array}$} & EASE1 & $\begin{array}{l}\text { I have positive experiences in use social media for } \\
\text { sharing experiences. }\end{array}$ & 3.67 & 0.750 & 1.1 & 5.6 & 25.8 & 59.6 & 7.9 \\
\hline & EASE2 & $\begin{array}{l}\text { I enjoy when I use social media for sharing } \\
\text { experiences. }\end{array}$ & 3.72 & 0.953 & 4.5 & 5.6 & 19.1 & 55.1 & 15.7 \\
\hline & EASE3 & $\begin{array}{l}\text { *I have negative experiences with use social } \\
\text { media for sharing experiences. }\end{array}$ & 2.36 & 1.014 & 23.6 & 32.6 & 28.1 & 15.7 & 0.0 \\
\hline & EASE4 & $\begin{array}{l}* \text { I feel anxious when I use social media for } \\
\text { sharing experiences. }\end{array}$ & 2.48 & 1.139 & 25.8 & 23.6 & 29.2 & 19.1 & 2.2 \\
\hline \multirow{4}{*}{$\begin{array}{l}\text { Personal Master } \\
\text { Experiences } \\
\text { (Sharing research } \\
\text { outputs) }\end{array}$} & PMSR1 & $\begin{array}{l}\text { I am very confident to use social media for } \\
\text { sharing research outputs. }\end{array}$ & 3.63 & 0.885 & 1.6 & 9.5 & 25.4 & 50.8 & 12.7 \\
\hline & PMSR2 & $\begin{array}{l}\text { I have good skills in use social media for sharing } \\
\text { research outputs. }\end{array}$ & 3.65 & 0.845 & 1.6 & 9.5 & 20.6 & 58.7 & 9.5 \\
\hline & PMSR3 & $\begin{array}{l}\text { I have experiences with social media platform (s) } \\
\text { that I use for Sharing research outputs. }\end{array}$ & 3.95 & 0.580 & 0.0 & 3.2 & 9.5 & 76.2 & 11.1 \\
\hline & PMSR4 & $\begin{array}{l}\text { I have attended training courses to improve my } \\
\text { ability in use social media for sharing research } \\
\text { outputs. }\end{array}$ & 2.57 & 1.228 & 22.2 & 34.9 & 9.5 & 30.2 & 3.2 \\
\hline \multirow{4}{*}{$\begin{array}{l}\text { Vicarious } \\
\text { Experience } \\
\text { (Sharing research } \\
\text { outputs) } \\
\text { Verbal Persuasion } \\
\text { (Sharing research } \\
\text { outputs) }\end{array}$} & VESR1 & $\begin{array}{l}\text { I have seen my colleagues use social media for } \\
\text { sharing research outputs. }\end{array}$ & 3.86 & 0.759 & 1.6 & 4.8 & 12.7 & 68.3 & 12.7 \\
\hline & VESR2 & $\begin{array}{l}\text { I have observed others' success in using social } \\
\text { media for sharing research outputs. }\end{array}$ & 3.84 & 0.723 & 0.0 & 4.8 & 20.6 & 60.3 & 14.3 \\
\hline & VPSR1 & $\begin{array}{l}\text { I have received encouragement from my } \\
\text { colleagues to use social media for sharing } \\
\text { research outputs. }\end{array}$ & 3.35 & 1.034 & 3.2 & 19.0 & 30.2 & 34.9 & 12.7 \\
\hline & VPSR2 & $\begin{array}{l}\text { I have received encouragement from my } \\
\text { institution to use social media for sharing research } \\
\text { outputs. }\end{array}$ & 3.10 & 1.027 & 4.8 & 25.4 & 33.3 & 28.6 & 7.9 \\
\hline \multirow{4}{*}{$\begin{array}{l}\text { Emotional } \\
\text { Arousal (Sharing } \\
\text { research outputs) }\end{array}$} & EASR1 & $\begin{array}{l}\text { I have positive experiences in use social media for } \\
\text { sharing research outputs. }\end{array}$ & 3.68 & 0.758 & 1.6 & 4.8 & 25.4 & 60.3 & 7.9 \\
\hline & EASR2 & $\begin{array}{l}\text { I enjoy when I use social media for sharing } \\
\text { research outputs. }\end{array}$ & 3.68 & 0.858 & 3.2 & 4.8 & 23.8 & 57.1 & 11.1 \\
\hline & EASR3 & $\begin{array}{l}\text { *I have negative experiences with use social } \\
\text { media for sharing research outputs. }\end{array}$ & 2.43 & 0.979 & 15.9 & 41.3 & 30.2 & 9.5 & 3.2 \\
\hline & EASR4 & $\begin{array}{l}* \text { I feel anxious when I use social media for } \\
\text { sharing research outputs. }\end{array}$ & 2.56 & 1.044 & 15.9 & 34.9 & 30.2 & 15.9 & 3.2 \\
\hline
\end{tabular}




\begin{tabular}{|c|c|c|c|c|c|c|c|c|c|}
\hline \multicolumn{10}{|c|}{ Appendix 2: Questionnaire's items and descriptive statistics (The impact of these Sources) } \\
\hline Variables & & Items & Mean & SD & 1 & 2 & 3 & 4 & 5 \\
\hline \multirow{2}{*}{$\begin{array}{l}\text { Personal Master } \\
\text { Experiences } \\
\text { (Sharing } \\
\text { experiences) }\end{array}$} & ImPMSE1 & $\begin{array}{l}\text { If I am confident about my abilities and skills in } \\
\text { the use of social media to share experiences, I will } \\
\text { be keen to use it. }\end{array}$ & 3.78 & 0.750 & 0.0 & 6.7 & 21.3 & 59.6 & 12.4 \\
\hline & ImPMSE2 & $\begin{array}{l}\text { If I am confident about my abilities and skills in } \\
\text { the use of social media to share experiences, I will } \\
\text { use it more frequently. }\end{array}$ & 3.67 & 0.927 & 2.2 & 9.0 & 23.6 & 49.4 & 15.7 \\
\hline \multirow{3}{*}{$\begin{array}{l}\text { Vicarious } \\
\text { Experience } \\
\text { (Sharing } \\
\text { experiences) }\end{array}$} & ImVESE1 & If I have seen more successes from others in the & 3.62 & 0.819 & 1.1 & 10.1 & 22.5 & 58.4 & 7.9 \\
\hline & & $\begin{array}{l}\text { use of social media to share experiences, I will be } \\
\text { keen to use it. }\end{array}$ & & & & & & & \\
\hline & ImVESE2 & $\begin{array}{l}\text { If I have seen more successes from others in the } \\
\text { use of social media to share experiences, I will use } \\
\text { it more frequently. }\end{array}$ & 3.60 & 0.938 & 3.4 & 10.1 & 21.3 & 53.9 & 11.2 \\
\hline \multirow{2}{*}{$\begin{array}{l}\text { Verbal } \\
\text { Persuasion } \\
\text { (Sharing } \\
\text { experiences) }\end{array}$} & ImVPSE1 & If I receive this encouragement continuously, I & 3.45 & 0.989 & 4.5 & 10.1 & 33.7 & 39.3 & 12.4 \\
\hline & ImVPSE2 & $\begin{array}{l}\text { will be keen to use it. } \\
\text { If I receive this encouragement continuously, I } \\
\text { will use it more frequently. }\end{array}$ & 3.47 & 1.001 & 4.5 & 10.1 & 32.6 & 39.3 & 13.5 \\
\hline \multirow{4}{*}{$\begin{array}{l}\text { Emotional } \\
\text { Arousal } \\
\text { (Sharing } \\
\text { experiences) }\end{array}$} & ImEASE1 & $\begin{array}{l}\text { If I have a positive feeling from using social } \\
\text { media to share experiences, I will be keen to use } \\
\text { it. }\end{array}$ & 3.93 & 0.735 & 1.1 & 2.2 & 16.9 & 61.8 & 18.0 \\
\hline & ImEASE2 & $\begin{array}{l}\text { If I have a positive feeling from using social } \\
\text { media to share experiences, I will use it more } \\
\text { frequently. }\end{array}$ & 3.92 & 0.757 & 1.1 & 2.2 & 19.1 & 58.4 & 19.1 \\
\hline & ImEASE3 & $\begin{array}{l}\text { *If I have a negative feeling from using social } \\
\text { media to share my experiences, I will not be keen } \\
\text { to use it. }\end{array}$ & 3.54 & 1.098 & 6.7 & 12.4 & 15.7 & 50.6 & 14.6 \\
\hline & ImEASE4 & $\begin{array}{l}\text { *If I have a negative feeling from using social } \\
\text { media to share my experiences, I will not use it } \\
\text { any more. }\end{array}$ & 3.39 & 1.154 & 9.0 & 13.5 & 20.2 & 43.8 & 13.5 \\
\hline \multirow{3}{*}{$\begin{array}{l}\text { Personal Master } \\
\text { Experiences } \\
\text { (Sharing } \\
\text { research } \\
\text { outputs) }\end{array}$} & ImPMSR1 & If I am confident about my abilities, skills, and & 3.86 & 0.840 & 1.6 & 4.8 & 19.0 & 55.6 & 19.0 \\
\hline & & $\begin{array}{l}\text { experiences in the use of social media to share } \\
\text { research outputs, I will be keen to use it. }\end{array}$ & & & & & & & \\
\hline & ImPMSR2 & $\begin{array}{l}\text { If I am confident about my abilities, skills, and } \\
\text { experiences in the use of social media to share } \\
\text { research outputs, I will use it more frequently. }\end{array}$ & 3.87 & 0.793 & 1.6 & 1.6 & 23.8 & 54.0 & 19.0 \\
\hline \multirow{3}{*}{$\begin{array}{l}\text { Vicarious } \\
\text { Experience } \\
\text { (Sharing } \\
\text { research } \\
\text { outputs) }\end{array}$} & ImVESR1 & If I have seen more successes from others in the & 3.92 & 0.867 & 1.6 & 6.3 & 12.7 & 57.1 & 22.2 \\
\hline & & $\begin{array}{l}\text { use of social media to share research outputs, I } \\
\text { will be keen to use it. }\end{array}$ & & & & & & & \\
\hline & ImVESR2 & $\begin{array}{l}\text { If I have seen more successes from others in the } \\
\text { use of social media to share research outputs, I } \\
\text { will use it more frequently. }\end{array}$ & 3.87 & 0.907 & 1.6 & 7.9 & 14.3 & 54.0 & 22.2 \\
\hline \multirow{2}{*}{$\begin{array}{l}\text { Verbal } \\
\text { Persuasion } \\
\text { (Sharing } \\
\text { research } \\
\text { outputs) }\end{array}$} & ImVPSR1 & If I receive this encouragement continuously, I & 3.71 & 0.906 & 1.6 & 7.9 & 25.4 & 47.6 & 17.5 \\
\hline & ImVPSR2 & $\begin{array}{l}\text { will be keen to use it. } \\
\text { If I receive this encouragement continuously, I } \\
\text { will use it more frequently. }\end{array}$ & 3.73 & 0.884 & 1.6 & 7.9 & 22.2 & 52.4 & 15.9 \\
\hline \multirow{5}{*}{$\begin{array}{l}\text { Emotional } \\
\text { Arousal } \\
\text { (Sharing } \\
\text { research } \\
\text { outputs) }\end{array}$} & ImEASR1 & If I have a positive feeling from using social & 4.05 & 0.551 & 0.0 & 1.6 & 7.9 & 74.6 & 15.9 \\
\hline & & $\begin{array}{l}\text { media to share research outputs, I will be keen to } \\
\text { use it. }\end{array}$ & & & & & & & \\
\hline & ImEASR2 & $\begin{array}{l}\text { If I have a positive feeling from using social } \\
\text { media to share research outputs, I will use it more } \\
\text { frequently. }\end{array}$ & 4.03 & 0.595 & 0.0 & 1.6 & 11.1 & 69.8 & 17.5 \\
\hline & ImEASR3 & $\begin{array}{l}\text { *If I have a negative feeling from using social } \\
\text { media to share research outputs, I will not be keen } \\
\text { to use it. }\end{array}$ & 3.56 & 0.980 & 6.3 & 7.9 & 17.5 & 60.3 & 7.9 \\
\hline & ImEASR4 & $\begin{array}{l}\text { *If I have a negative feeling from using social } \\
\text { media to share research outputs, I will not use it } \\
\text { any more. }\end{array}$ & 3.35 & 1.003 & 7.9 & 11.1 & 22.2 & 55.6 & 3.2 \\
\hline
\end{tabular}

